\title{
電磁波シールド纎維の開発と応用展開
}

\section{Development and Application of Shielding Fabrics}

\section{1.はじめに}

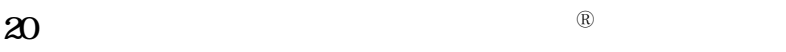
手した。当時はコンピューターを代表とする $O A$ 機器が普 及し始めた時期で、電磁波の人体への影響や他通信機器の 誤作動等がクローズアップし始めた頃である。

社会環境の変化は新事業創出のチャンスであり、技術面 では無電解メッキの手法を使えば導電性、電磁波シールド 性を繊維に付与でき、電磁波対策素材として用途開拓か期 待できると考えた。

用途開拓には時間を要し、導電性繊維がパソコンの電磁 波シールド材として特徵を認められてからは、パソコンを 中心とする情報機器の進展に伴い順調に弚のマーケットを 拡大してきた。

\section{2 . 導電性纎維『プラット ${ }^{\circledR} 』$}

\section{1 電磁波と電磁波障害}

電磁波とは何か。表 1 に示すように、1 Hz 以下の超長波 から赤外線、可視光線、紫外線、放射線に至るまですべて が電磁波であるが、情報機器においては長波からマイクロ 波が最も重要視される。

電磁波障害は、人体への影響と情報機器間における誤作 動の二つに大別される。人体への影響については、未だ定 説はないようだが何らかの影響を人体に与えているとの認 識は一致しているようである。電磁波の有害を唱える図書 も多く見うけられ、また公的機関でも、調查、対策に乗り 出しているとの報道が幾度も新聞をにぎわせている。

一方電子機器間のノイズによる誤作動も心藏ペースメー カーの動作不全、航空機の機器の誤作動等々か報告され、 航空機に搭乗の際とか、病院内では、携帯電話の電源を切 ることは常識になっている。

この例が示すように、電磁波には善悪二つの側面がある。

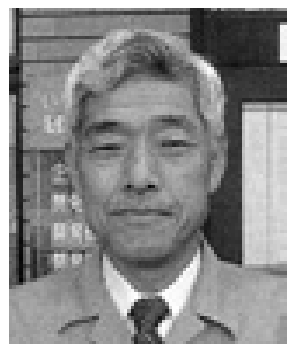

SUSUMU TAKAGI

セーレン(姝)技術開発部門開発研究第二部

部長、工学士

于 918-8560 福井市毛矢 1丁目 10-1

Tel : 0776-35-2112 Fax : 0776-35-2115

E-mail : takagi@seiren.co.jp

〈専門〉䋊維の機能化、複合化

〈趣味〉スポーツ観戦、球技
携帯電話は電磁波が存在することにより成り立ち、非常に 便利である反面、航空機、病院、通信機器の誤作動を引き 起こす可能性があり、大变な惨事の原因になり得、人体へ の影響も懸念されている。

このことからからも、電子機器における電磁波対策は単 に電磁波を機器外に出さないだけでなく、電磁波の善悪の バランスを考える必要がある。具体的には、電子機器から 他に悪影響を与える樣な電磁ノイズを発生させないことと、 樣々な電磁環境においても機器システムか影響されずに正 常に機能することが必要である。

表 1 電磁波の種類と利用分野

\begin{tabular}{|c|c|c|c|}
\hline \multicolumn{2}{|c|}{ 名 称 } & 周波数帯 & 主な利用分野 \\
\hline ULF & 超超長波 & $0.03 \sim 3 \mathrm{~Hz}$ & \\
\hline ELF & \multirow[t]{2}{*}{ 超長波 } & $3 \sim 3,000 \mathrm{~Hz}$ & 家庭電気製品、高圧電線 \\
\hline VLF & & $3 \sim 30 \mathrm{KHz}$ & 電磁調理器、無線航行 \\
\hline LF & 長波 & $30 \sim 300 \mathrm{KHz}$ & 無線、気象通報 \\
\hline MF & 中波 & $300 \sim 3,000 \mathrm{KHz}$ & 放送、無線、船舶通信 \\
\hline $\mathrm{HF}$ & 短波 & $3 \sim 30 \mathrm{MHz}$ & 航空機通信、短波放送 \\
\hline VHF & 超短波 & $30 \sim 300 \mathrm{M} \mathrm{Hz}$ & TV 放送、航空管制通信 \\
\hline UHF & \multirow{2}{*}{$\begin{array}{l}\text { 極超短波 } \\
\text { マイクロ波 }\end{array}$} & $300 \sim 3000 \mathrm{M} \mathrm{Hz}$ & TV 放送、携帯電話、無線 \\
\hline SHF & & $3 \sim 30 \mathrm{GHz}$ & 衛星放送、通信、LAN \\
\hline \multirow[t]{2}{*}{ EHF } & ミリ波 & $30 \sim 300 \mathrm{GHz}$ & 各種レーダー、衛星通信 \\
\hline & サブミリ波 & $300 \sim 3000 \mathrm{GHz}$ & 光通信システム \\
\hline \multicolumn{2}{|c|}{ 赤外線 } & $\sim 384 \mathrm{~T} \mathrm{~Hz}$ & 加熱 \\
\hline \multicolumn{2}{|c|}{ 可視光線 } & $\sim 789 \mathrm{THz}$ & \\
\hline \multicolumn{2}{|c|}{ 紫外線 } & $\sim 30,000 \mathrm{~T} \mathrm{~Hz}$ & レーザー \\
\hline \multicolumn{2}{|c|}{ X線 } & $\sim 3,000$ 万 $\mathrm{THz}$ & 医療機器 \\
\hline \multicolumn{2}{|c|}{$\gamma$ 線 } & 3,000 万 THz〜 & 科学観測機器 \\
\hline
\end{tabular}

\section{2 電磁波シールド性}

本題でもある電磁波シールド性に付いて若干触れておく。

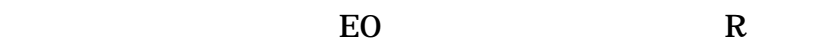
部吸収 $(A)$ 、内部反射損失 $(B)$ 及び透過波 $(E 1)$ に分かれる。 シールド効果 $(S E)$ との関係は

$\mathrm{SE}=\mathrm{A}+\mathrm{R}+\mathrm{B}$

シールド効果は次の式で求められる。

$\mathrm{SE}(\mathrm{dB})=20 \log E 0 / E 1$

*磁界波に付いては省略

$E O:$ シールド材が無い時の電界強度 $(\mathrm{V} / \mathrm{m})$

E1 : シールド材を透過した電界強度 $(\mathrm{V} / \mathrm{m})$

一般に電磁波シールド材には最低 40dB、つまり $99 \%$ 以 上の遮蔽効果が求められる。

繊維とかプラスチックは電磁波に対し透明であり照射さ 


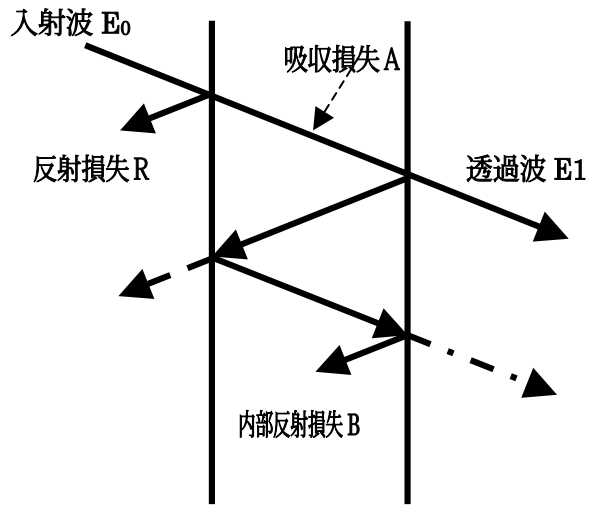

図 1

れた電磁波は物質を透過する。一方金属を代表とする導電 性物質は光の界面で電磁波のインピーダンス不整合により、 あたかも光に対する鏡の樣に反射する性質がある。

つまり導電性物質は電磁波シールド性も併せ持つており、

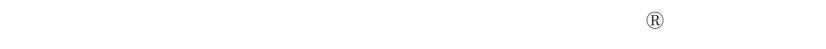

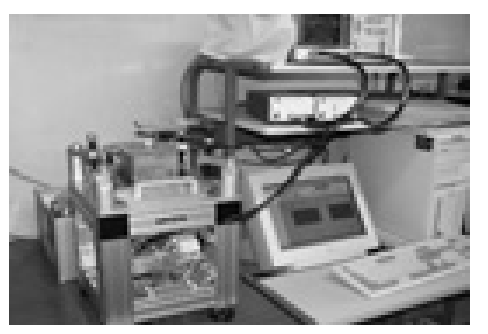

図 2 KEC 法セル構造と測定の樣子

波シールド繊維でもある。

素材のシールド性能評価法としてはアドバンテスト法や KEC 法が知られている。この測定法は図 2 に示すように シールドボックスの中央を試料で遮り前後での発信電波の 減衰を評価する方法である。

\section{3 導電性繊維『プラット ${ }^{\circledR} 』 の$ 特徵}

導電性㵶維『プラット ${ }^{\circledR}$ の構造は图 3 に示すように、 織物の系一本一本の表面が金属化された構造をしている。 繊維一本一本に金属薄膜を形成することにより䋐維の特徵 を生かしたまま金属の特性を付与することが出来る。従来 のフィルムラミネート、樹脂コーティング手法では繊維織 物全体を導電化することはできず、柔軟性も損なわれる。

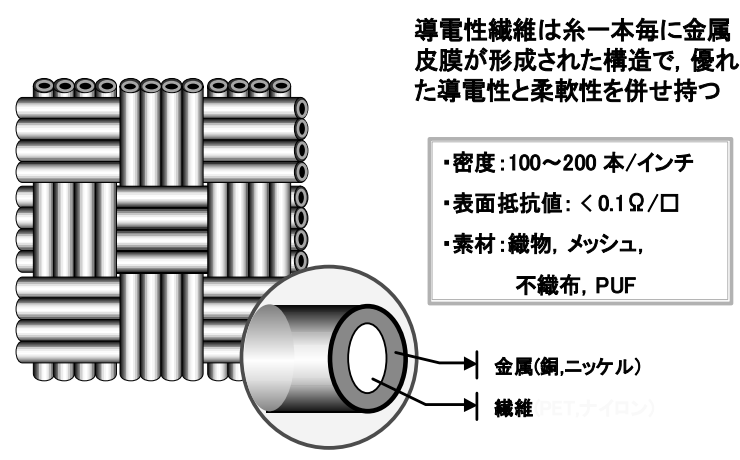

図 3 導電性繊維の構造
蒸着、スパッタリング等の気相系処理では織物の表裏全体 を導電化することは困難であり、また产の導電性のレベル は低い。凹凸のある複雑な形状の繊維布帛の金属化処理は 溶液系処理である無電解メッキ手法が最良の手法であり、

『プラット ${ }^{\circledR}$ は本法を採用している。

繊維に無電解メッキにて金属薄膜を密着性良く複合化す ることにより、金属箔並の導電性を得ることができる。当 社で生産している平均的な導電布の電気抵抗值は 10 50 $\mathrm{m} \Omega / \square$ である。

金属を複合することにより瀻維に電磁波シールド性が付 与される。当社では市場の要求する電磁波シールド性を満 たすべく商品を設計製造しており、弚の商品の多くは40dB (遮蔽率 99\%) 100dB (遮蔽率 99.999\%) の性能を有してい る。

繊維の第一の特徵は柔軟でフレキシビリティーに富むこ とにあり、この点で繊維に勝る素材は他に見あたらない。 また軽量で強いという特徵も他素材の追随を許さない。同 一断面積の系で支えられる重量は衣料用の ポリエステル、ナイロンの系でも鋼材を上 回っている。

構造の多樣化も他素材を圧倒している。 ポリエステル、ナイロン、アクリル等々系 組成の多彩さ、樣々な形状の系断面、織物、 丸編み、トリコット、不織布等々多種多樣 なシート化手法と弚の構造等々……長年 瀻維業界が培ってきたこれら技術は他の素材、他の業界で は到底考えられない世界といえる。

当社はこの多樣性に富む纎維素材と金属とを複合製造す るに当たっては、100 余年にわたり培ってきた繊維加工技 術をフルに活用している。布帛設計、金属と䋊維の密着性、 製造装置、管理技術、評価技術のいずれもが従来の瀻維加 工を基に深化、展開した技術である。

『プラット ${ }^{\circledR}$ 『はシールド材として必要な性能、耐久性 をはじめユーザーの要求特性を盛り込んだ商品を設計し市 場に供給している。(商品性能例 图 4)

当社では、繊維の特徵を最大限に生かし、他素材では出 来ない特性の導電布を設計することで、従来素材に打ち勝 ち、新たな市場の創生と事業拡大をはかってきた。关の代 表か情報機器類の電磁波シールド材市場である。

\section{4 電磁波対策と電磁波シールド纎維}

今や必須となった情報機器の電磁波対策としては次の手

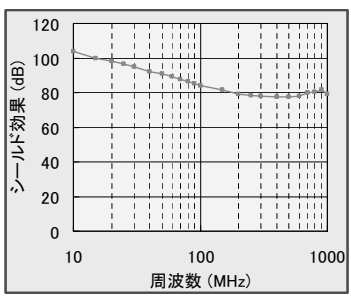

シールド性評価結果

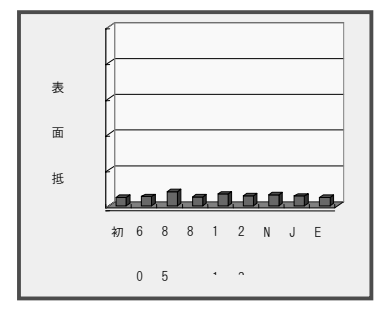

耐久性性評価結果
図 4 導電性繊維の性能 
法がよく用いられる。

(1)基盤と筐体を電気的に一体化することにより電磁波発 生の低減をはかる。

(2)筐体本体、光の隙間、ケーブルからの電磁波の漏れを、 電磁波シールド材で被覆する。

(3)ディスプレー等の空材に付いては可視光線が透過可能 な電磁波シールド材で覆う。

(1)はいわゆるアース(グランディング)と呼ばれ、基盤と 基盤、基盤と筐体を導電性物質でつなぎ電気的一体化で電 磁波の低減をはかる手法である。パソコンのグランディン ク部材としては次に示すような特性が要求される。

i ) 接触抵抗が小さい。

$\rightarrow$ 基盤に挟むだけで導通が取れる。(図 5)

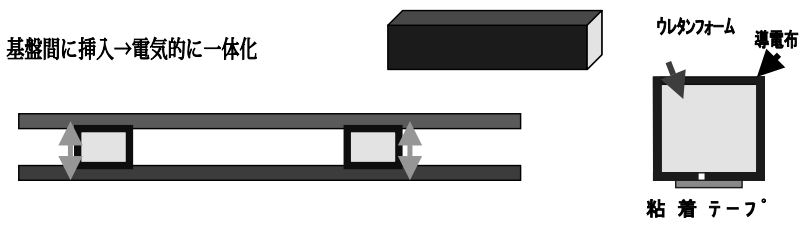

図 5 グランディング

ii ）残留応力が小さい。

$\rightarrow$ 基盤のストレスが小さこと。

iii ）基盤間の隙間が一定でなくてもアース(電気的一体化) が可能なこと

従来はスプリングフィンガーストリップと呼ばれる金属 製のスプリングとか、ワイヤーメッシュと呼ばれるゴム製 心材に金属製ワイヤーメッシュを被覆したものを基盤同士 及び基盤と筐体の隙間に挿入していたが、隙間が一定しな いこと、基盤に強いストレスが加わる等の問題があった。

柱状のウレタンフォームに柔軟性の高い導電性布帛を巻 いた、いわゆる導電性布巻きガスケット(図 5) と呼ばれる ものか提案されると、乥の柔軟な弾性と表面導電性が高く 評価され、この用途では他を圧倒しこの市場を完全に制覇 した。

パソコンでの実際の使用例を図 6 に示す。

一方筐体とかケーブル等からの電磁波の漏れに対しては、

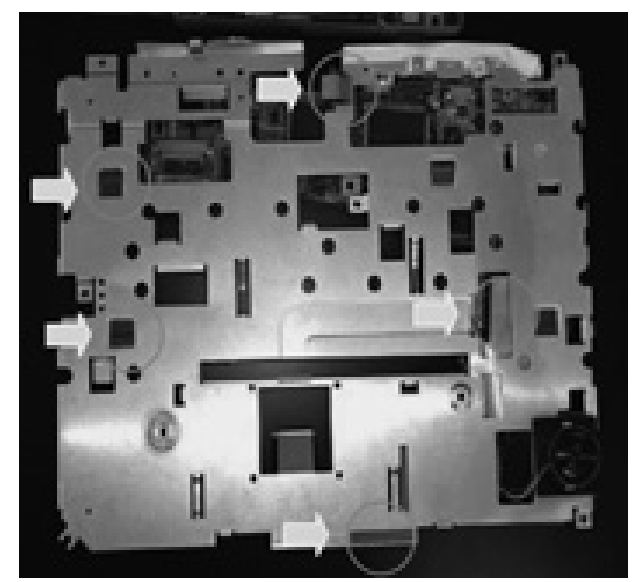

図 6 パソコンの基盤 ( ○部が導電性布巻きガスケット)
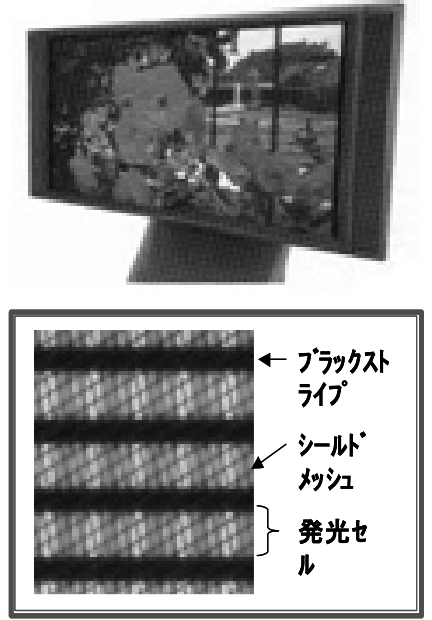

図 7

光の隙間やケーブル自体を電磁波遮蔽材で覆う方法が用い られる。従来筐体の隙間には導電性ゴム等を充填する方法 により、ケーブルからの漏れに対しては金属箔をケーブル に被覆することにより対策するのが一般的であった。しか し筐体の隙間対策も導電性布巻きガスケットが兴の使いや すさ、性能等で他を圧倒してきた。ケーブルの電磁波対策 は、高い電磁波シールド性と高度なフレキシビリティを併 せ持つ導電性㵶維製の導電性テープが作業性、性能の両面 で高く評価され、金属箔から市場を奪ってきた。

ディスプレーは可視光透過性が必須であり、光の用途に 用いる電磁波シールド材は可視光透過性と不用電磁波遮蔽 性の両立が必要である。

この特性を持つ電磁波シールド材として導電性薄膜を フィルム上に形成した透明導電膜と呼ばれるもの、銅箔を フォトリソ法を用いフィルム上にメッシュを形成したエッ チングメッシュと呼ばれるもの光して表面を金属化した緎 維メッシュの三種の商品が存在する。

最近、薄型の大型テレビが従来のブラウン管テレビに替 わり家電商品販売店頭をにぎわしている。この中で40イ ンチを超える大型テレビは PDP(プラズマディスプレーパ ネル)が優位であり市場を伸ばしている。

このPDP は 300 万個を越えるプラズマ発光セルを持ち、 原理的に多量の不用電磁波が放出され、必然的に電磁波対 策が必要となる。(图 7)

透明導電膜は、メッシュ素材に比ベ電磁波シールド性が 劣り、電磁波規制の厳しい民生用、輸出用にはメッシュが 使用される。

当社は、メッシュ織物が可視光透過性を持ち、メッキす ることにより電磁波シールド性との両立が可能であること に着目、数年前から PDP 用電磁波シールド材に特化して、 製造販売している。図 7 にシールド材として使用されてい る状態を拡大写真で示した。

2.5 綫維、素材の特徵を生かした商品例

導電性緎維事業を今後さらに拡大するには、従来他の素 
材では満たされなかったニーズに対して纎維の特性を生か し解決するか、全く新たな市場を創生するしかない。この 市場では異業種、異素材と競合するのが常でありこの中で 勝ち残って行くには、緎維の他にない特性、多樣性を十分 に生かす必要がある。時には従来の概念をうち破る商品設 計、工程設計が必要となる場面もある。以下繊維、素材の 特徵を生かした『プラット ${ }^{\circledR} 』$ の商品例を示す。

i )繊維の断面形状を生かした例

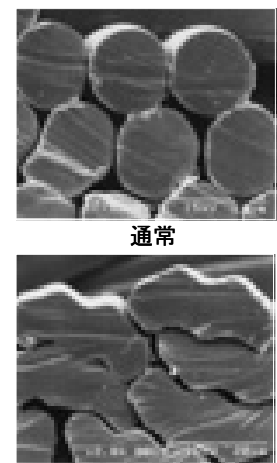

異形断面糸

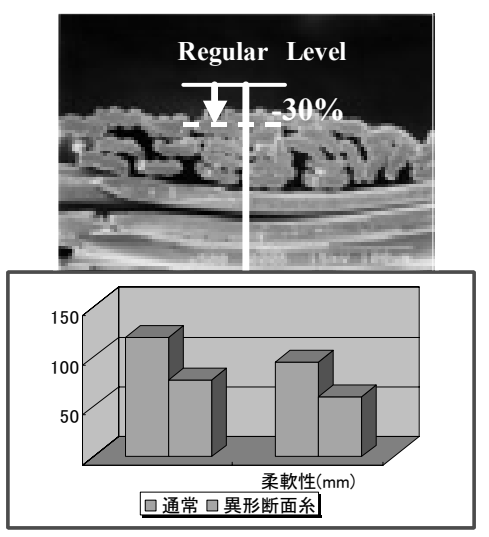

図 8
非常に薄い導電布の要求に対して、開発した導電布の例 を図8に示す。通常の丸断面の繊維を扁平系に変えること により導電布の厚みを $30 \%$ 薄くすることができた。導電 布の厚みを薄くすることにより柔軟性が向上し電磁波シー ルド性も向上することができた。

ii )素材の特徵を生かした例

布巻き導電性ガスケットがグランディング材、筐体隙間 の遮蔽材として優れた特性を有していることを述べたが、 顧客ニーズを全て満たしているわけではない。

導電性布巻きガスケットは導電布をウレタンフォームに 巻く必要があるので製造できる形態に制限が生まれる。例 えば、円盤状とか星形のものを作ることはできない。厚さ $1 \mathrm{~mm}$ 程度の薄い物を作る事も製造する上で大変厄介であ る。一方コネクター部のガスケットを製造する場合、布巻
きガスケットを作った後打ち抜く為製造工程が長く、コス 卜も高くなる。(図 9 参照)

これらの課題を解決すべく導電性ウレタンフォームを開 発した。これはウレタンフォームと繊維布帛をフレームラ ミ技術で強固に張り合わせた上でメッキ加工することによ り素材全体が均一に金属化され、上記課題を一気に解決で きた。(図 9参照)

この商品開発に於いては、ウレタンの劣化対策がポイン トであった。

劣化対策は、ウレタンの組成、改質剂、フォーム構造の 改良、めっき手法の改良で目標をクリアーした。2年以上 に及、洏久促進試験をクリアーしており、耐久性には自信 をもっている。

iii )PDP 用電磁波シールド材

PDP は原理的に不用電磁波が放出され、ディスプレー に電磁波対策が必要であり当社では繊維メッシュを特化さ せ供給していることはすでに述べた。

PDP ではパネルの保護、電磁波対策、色調整、光反射 防止、赤外線カット等を目的に本体の前に前面板が装着さ れる。(図 10)

前面板に用いられる電磁波シールド材は(1)可視光透過性 (2)色再現性、反射防止性(画像識別、コントラスト向上)が 必要である。

この開発において最も大きな課題は、我々が従来培って きた纎維加工技術、設備では市場ニーズを満たすことが出 来ないことであった。

当時、繊維メッシュは市場に存在したが、市場が求める 可視光透過率と電磁波シールド性を十分両立させることは 出来なかった。弚れを実現する方法は、繊維を細くした上 で系間を広くしたメッシュの実現と光れをメッキ加工する 製造技術の開発しかなかった。

当時の概念では乥の樣なメッシュでば目ヨレ”と呼ぶ 織物の組織崩れが避けられないと思われた。また大型ディ スプレーとして 40〜50 インチサイズの商品が無欠点であ ることが求められることも従来の繊維織物の概念とは大い

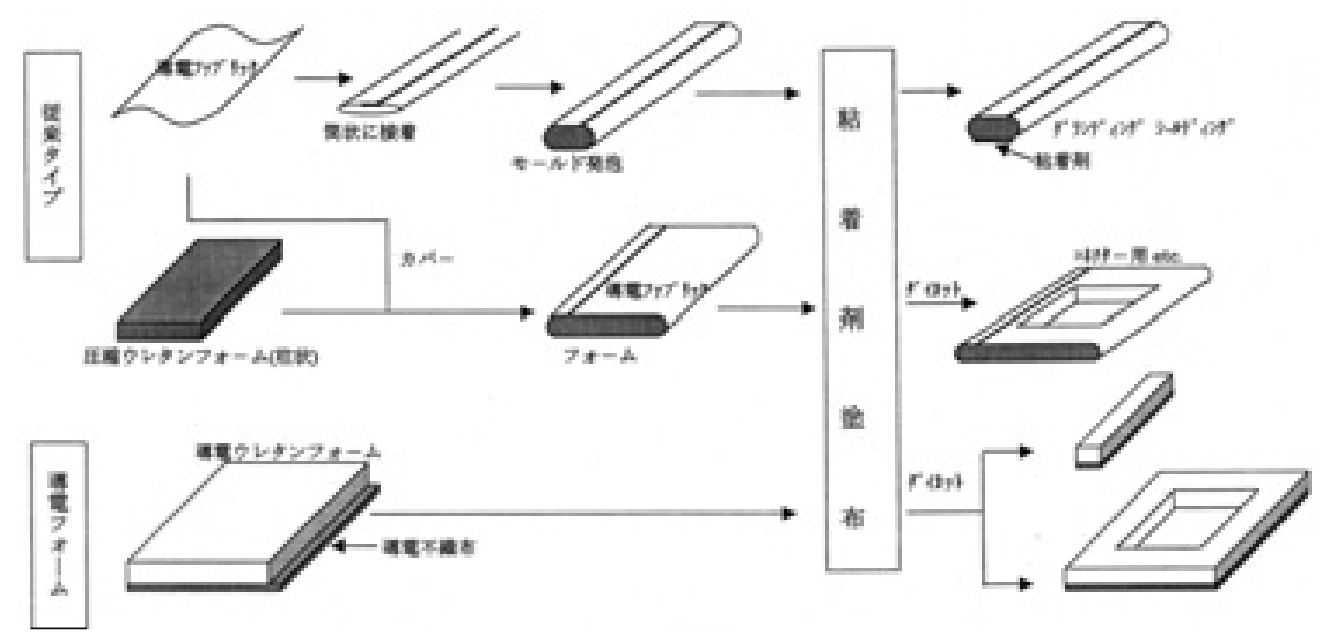

図 9 導電性ウレタンフォームの特徵 


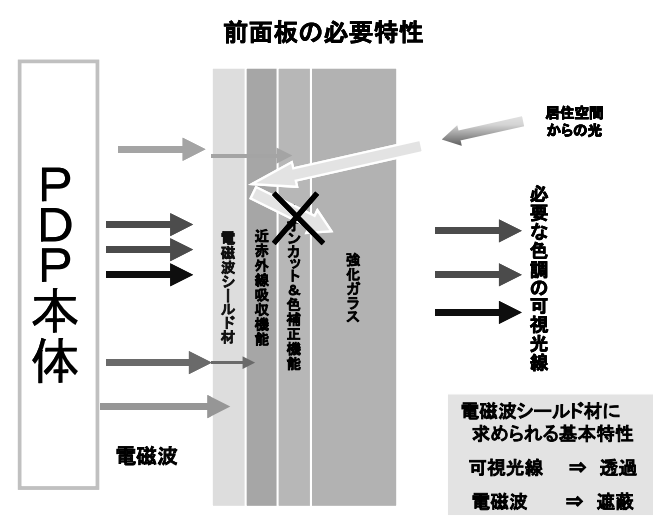

図 10

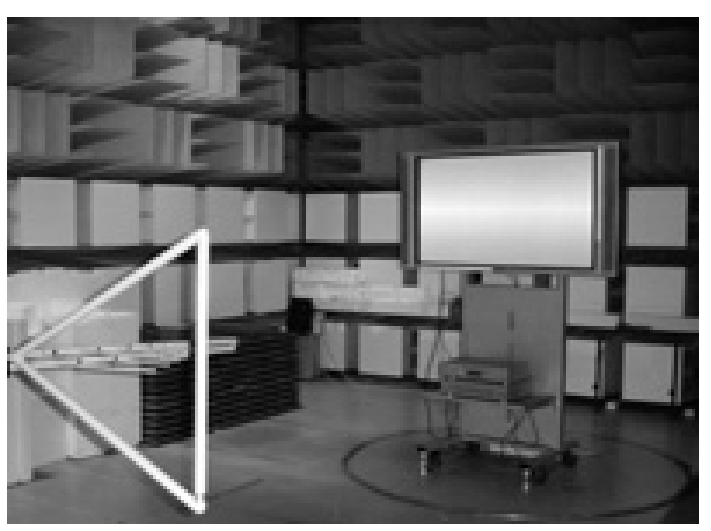

图 11 評価風景

\section{にかけ離れていた。}

シールド材の新たな用途を開拓したいとの強い思いで、 当社は繊維メーカー、製織メーカーの多大な協力も得てこ の課題を乗り越えることが出来た。今では繊維メッシュな らではの手法で、反射率低減を実現し、市場でも光の優位 性か認められている。

纎維メッシュを装着しての評価の樣子、及び光の結果を 図11〜図 13 に示す。

\section{3. 終わりに}

導電性㵶維開発に当たっては常に次の三点を意識してき
た。

(1)繊維、繊維加工という基盤技術に立脚した開発で異業 種との競合に勝つ

(2)市場要求を満たす最適設計、開発

素材、加工、設備、評価技術

(3)中国市場でも戦える競争力

特化技術と徹底した原価低減

開発を開始してから、二十年余を経過し、数年前から電 磁波シールド材の市場も膨らみ、当社の電磁波シールド材 事業も急成長してきた。今後も繊維の特徵を生かし商品開 発、用途開発を続けてゆく所存である。

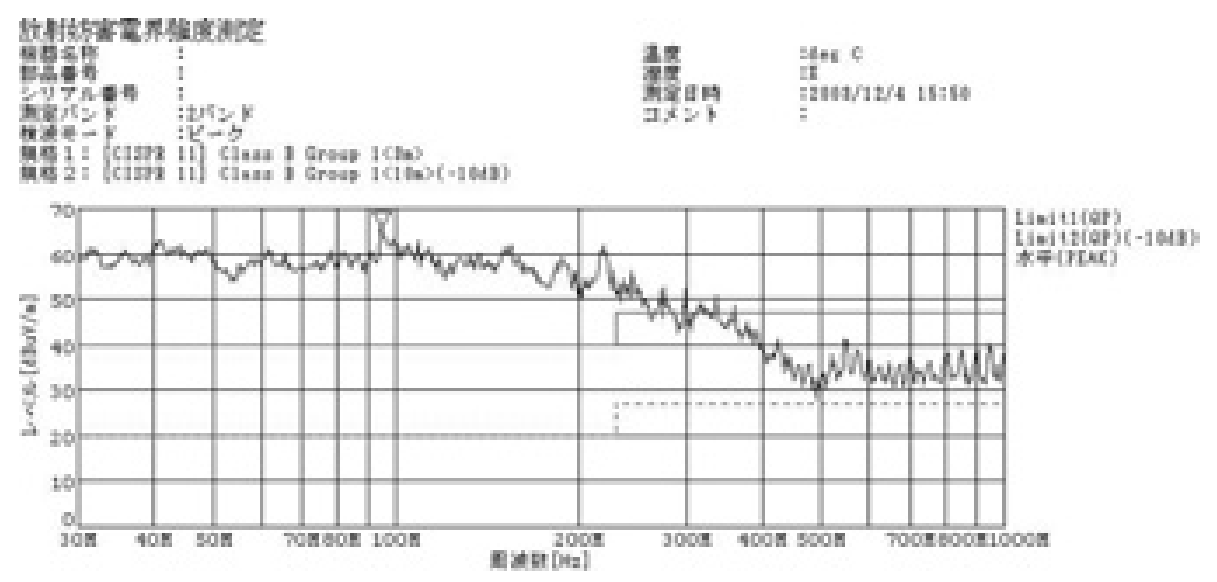

図 12 シールド材無し

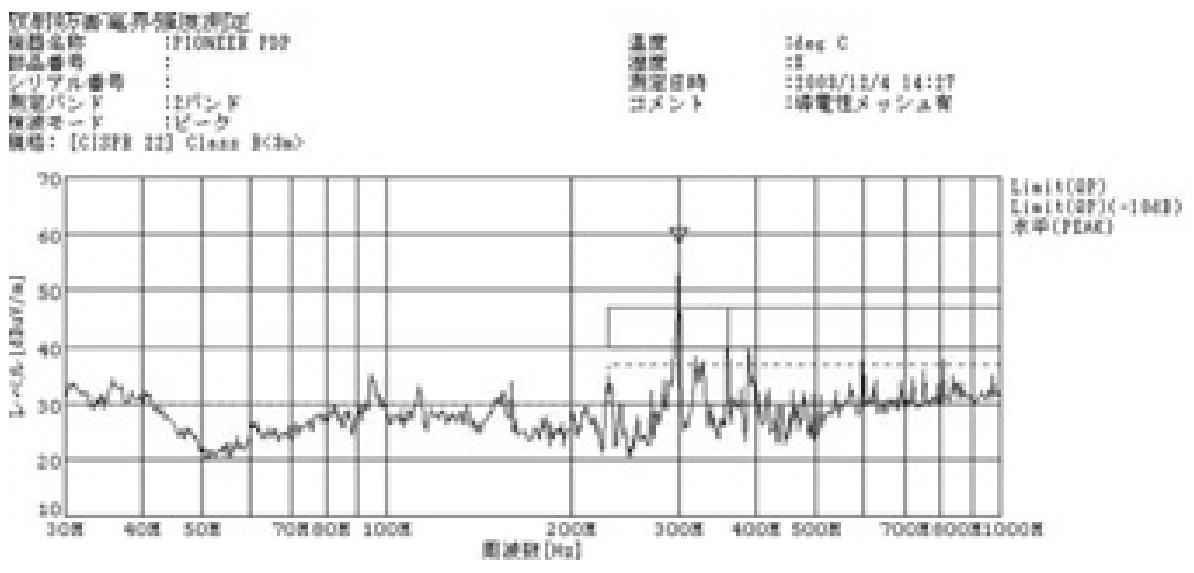

図 13 シールド材装着 